\title{
Article \\ Socio-economic factors of rural entrepreneurs that influence agricultural development in Antioquia
}

\author{
Francisco Arias ${ }^{1,2 *}$, Gabriela Ribes ${ }^{1}$, Luis Garces ${ }^{2}$ and Diana Arango ${ }^{3}$ \\ 1 Universitat Politècnica de València, Camí de Vera, s/n, 46022 València, Valencia, España. \\ 2 Corporación Universitaria Americana, Carrera 42 \#52-36, Medellín, Colombia. \\ 3 Instituto Tecnológico Metropolitano, Calle 73 No. 76A - 354, Vía al Volador, Medellín, Colombia. \\ * Correspondence: fraarvar@doctor.upv.es
}

\begin{abstract}
Entrepreneurship can help revitalize rural territories and agricultural development; consequently, it is important to know aspects that allow a better understanding of the subjects that undertake in the countryside, in this case, sociodemographic aspects, related to students and graduates of five Faculties of Agricultural Sciences in the Department of Antioquia in Colombia. For this purpose, a previously validated questionnaire was used, collecting 427 complete responses. Chi-square statistical tests were performed to determine the degree of association of entrepreneurial activity with measured sociodemographic variables such as gender, age, marital status, schooling, family environment, and dependents. Once the existence of associations between the variables was verified, a multiple correspondence analysis was performed to identify patterns and trends. A greater favorability for entrepreneurship was found in those subjects belonging to the upper strata of the population, mostly men, with postgraduate studies, from wealthy families, while the poorest and women are mainly oriented towards job search.
\end{abstract}

Keywords: Entrepreneurship, rural, millennials, Antioquia

\section{Introduction}

Entrepreneurship has become a career option as opposed to the traditional alternative of people looking for a job, the reasons which they consist of are varied, but there is a strong presence in the literature that mentions the existence of positive factors determined by 'pull' and 'push' that drive peoples motivations [1]; which is addressed by Reynolds, Camp, and Autio [2]; who taking these factors, introduce the concept of entrepreneurship by opportunity and by necessity.

The GEM project considers that necessity entrepreneurship is usually due to the lack of job alternatives or economic difficulties, while opportunity entrepreneurship is focused on taking advantage of market situations or personal interests [3], and which has a more positive effect on economic growth and aspirations than those who only undertake out of necessity, also reporting a direct impact on the level of satisfaction [4-6].

Other factors influence entrepreneurship such as personal, social, cultural, family, demographic, environmental, political, institutional, and macroeconomic factors [7-9], in addition to socioeconomic aspects in the individual, such as educational level, experience, gender, environment and economic condition [1,10-13].

Motivation for entrepreneurship is key to the development of a society [14]; the motivation studies developed by McClelland establish a relationship between the need 
for achievement and the economic development of a group or a society and generate understanding of the motivation for entrepreneurship [15]; In this regard, motivation is understood as a psychological process that can arise from a personal or environmental need, in which social, cultural and situational factors intervene [16] and that develops in three steps [17], starting with the establishment of a goal by the individual as the option to undertake, the choice of how to achieve it, which favors the entrepreneurial intention and then put it into action, trying to establish conditions for the enterprise to last over time [18].

Shapero's entrepreneurial event theory [19], mentions the importance of the context to promote entrepreneurship, as well as the viability expressed in resources, knowledge, and experience [20], with sociodemographic aspects such as family, education, and socioeconomic structure influencing entrepreneurial intention [21]. Also, Shapero alludes to the culture that promotes values associated with the creation of enterprises, the economic independence of the subjects, and their risk-taking, present in regions such as Smoeland in Switzerland, Cork in Ireland, and Antioquia in Colombia [19,22].

The Department of Antioquia has been recognised for having an entrepreneurial culture, through highlighting its inhabitants characteristics such as personality, attitude, intention, personal orientation to business and networking, which has facilitated establishing an entrepreneurial base [20,23]; without forgetting the importance of the territory that has a rural extension of $99.8 \%$ and contributes $6 \%$ of the regional GDP, whose figures have been falling at rates of 0.1 to $0.5 \%$ each year [24,25].

This raises the need to revitalize rural territories and promote entrepreneurship to attract people and resources to the countryside, among them could be the so-called millennials [26,27], who have shown greater entrepreneurial activity in Colombia, compared to other age groups, reaching a figure of $65.7 \%$ of the country's initiatives [28].

Because of the above, the purpose of this study is to determine which sociodemographic aspects influence rural entrepreneurship promoted by university students belonging to faculties of agricultural sciences in Antioquia (Colombia)

\section{Literature review.}

Entrepreneurship has had a conceptual evolution starting from Richard Cantillon, who argued that the entrepreneur was a risk-taker in an environment of uncertainty $[29,30]$, while Schumpeter places it as a promoter of economic growth through innovation and generation of changes in the markets [31]; McClelland as an achievement-oriented person, while Kizner associates it as an individual who can recognize opportunities [32], Shapero considers it as a person who introduces changes [31], while Druker sees it as a person who can innovate and generate wealth with existing resources [32].

When talking about the term entrepreneurship, it can be noted in the literature that there is no consensus on a single definition (see Table 1), with approaches from perspectives such as economic, psychological, organizational, and institutional [33], and although efforts have been made to generate approaches between the concepts, it can be noted that each organization has its definitions, theoretical positions and even variations on how to measure it [34]. 
Table 1. Definitions of entrepreneurship

\begin{tabular}{|c|c|c|}
\hline Institution & Definition and measurement & Authors \\
\hline GERA - GEM Project & $\begin{array}{l}\text { Any business initiative (including self-employment), which is } \\
\text { in the market for a period of up to } 42 \text { months, among the } \\
\text { population aged } 18 \text { to } 64 \text { years old. }\end{array}$ & $\begin{array}{l}\text { Reynolds [34,35], } \\
\text { Singer et al [36], } \\
\text { Autio y Wong [37]c }\end{array}$ \\
\hline $\begin{array}{c}\text { EIM Business \& Policy } \\
\text { Research }\end{array}$ & $\begin{array}{l}\text { Total number of unincorporated and incorporated } \\
\text { self-employed (business owners) outside agriculture, hunting, } \\
\text { forestry, and fishing industries, who take up self-employment } \\
\text { as their primary activity. }\end{array}$ & Van Stel, et al [38] \\
\hline World Bank & $\begin{array}{l}\text { The activities of an individual or a group intended to initiate } \\
\text { economic activities in the formal sector under a legal form of } \\
\text { the company. }\end{array}$ & Klapper, et al [39] \\
\hline GEDI & $\begin{array}{l}\text { The dynamic, institutionally integrated interaction between } \\
\text { entrepreneurial attitudes, entrepreneurial capabilities, and } \\
\text { entrepreneurial aspirations on the part of individuals, which } \\
\text { drives the allocation of resources through the creation and } \\
\text { operation of new enterprises. }\end{array}$ & Acs, Szerb, Autio [40] \\
\hline OECD- Euroestat & $\begin{array}{l}\text { The appearance of a new production unit. This may be due to } \\
\text { an authentic birth of the unit, or creations by mergers, } \\
\text { breakups, spin-offs, or through the reactivation of inactive } \\
\text { companies. }\end{array}$ & OECD [41] \\
\hline
\end{tabular}

Source [34]

The field of entrepreneurship research has become dynamic. In this regard, Chandra [43] identified 46 relevant research topics, in addition to other topics that are being addressed by the literature, such as networking, decision making, social and informal entrepreneurship [44]; international entrepreneurship [45], as well as sustainable [46,47] and rural entrepreneurship [48,49].

Rural entrepreneurship, whose work began to be published in the 1980s [50], has been the subject of study by academics who have attempted to conceptualize it, such as Wortman, who tries to define it in terms of creating and innovating in a rural environment, which has led to works that attempt to define typologies of entrepreneurs [51], types of entrepreneurship [48] and conceptual evolution [49], to make room for ventures that no longer focus only on the agricultural function, giving space to other products and services that use resources and capabilities to create, develop, establish or transform entrepreneurial initiatives in a rural environment [52].

Countries with a broad rural vocation are interested in promoting entrepreneurial activity to revitalize rural areas and promote economic development. In this regard, projects such as GEM have sought to analyze entrepreneurial activity in urban and rural areas at the international level [53], highlighting the relevance of socioeconomic factors in entrepreneurial activity, which has also been described by several authors in the literature.

Among the aspects that relate entrepreneurial activity with socioeconomic factors are variables such as gender, age, educational level, income [54-59], marital status, and socioeconomic stratum [60,61]; as well as parental education and family environment $[62,63]$. Taking into account the above, it is important to describe the findings related in the literature, around the mentioned sociodemographic variables that affect entrepreneurial activity [55]. 


\subsection{Gender}

There is a range of literature that analyzes the gender perspective in entrepreneurship, in which it has been found that men have a greater presence in entrepreneurship than women [54], who have to overcome social, cultural, family, cognitive, and access to financing barriers [64]; This is in addition to a lower self-confidence in entrepreneurial skills compared to men [65]; gender differences have even been studied down to the level of language, finding that the linguistic structures in several countries reinforce stereotypes against women, which affects entrepreneurial activity [66].

Recent studies suggest that gender gaps have been closing in some developed countries [67], and where gender equity motivates women to become entrepreneurs [68]; although differences persist [69]; a relationship has been found between self-efficacy and the environment, formal institutions, sociodemographic aspects, and culture, which create configurations that favor the entrepreneurial activity of women and men [70].

\subsection{Age}

Age is another explanatory variable related to entrepreneurial activity, although young people are more drawn toentrepreneurship given their ability to keep up to date with knowledge, the search for opportunities, and the implementation of innovations; experience plays a fundamental role in the consolidation of entrepreneurship [54,71].

Studies have shown that graduates under 30 years of age increase the probability of entrepreneurship [21], and it has been found that older entrepreneurs have a higher rate of self-employment than their younger counterparts [61]; studies have found an inverted $\mathrm{u}$-shaped relationship between age and entrepreneurial activity [71,72].

The GEM report for Colombia also agrees that age is a factor that influences entrepreneurial activity; it was found that the age range between 18 and 44 years, brings together $64.2 \%$ of nascent and new ventures, while established entrepreneurs are aged between 45 and 54 years [28,73].

\subsection{Education}

It has been found that the level of education is relevant for entrepreneurial activity [65], although this is not necessarily always the case, since better preparation also affects the possibility of being hired by a company, which would suggest a negative relationship between the level of education of a subject and the preference for self-employment in certain contexts [74]; however, being in a better educational position also affects the potential individuals have given their ability to explore opportunities [71].

Some studies mention the positive links between entrepreneurship education and entrepreneurship in university contexts [75-77], however, there are doubts about the impact [78], since there are mixed and sometimes contradictory results [79,80]; requiring a connection between pedagogical objectives and program design [81]; however, its potential to motivate students to create businesses in the face of economic, social and political challenges imposed by the markets is recognized [59]. It is also mentioned that "educational level is a more important predictor of a person's occupation than background characteristics, such as occupation or education of the father or mother" [82],

The GEM report for Colombia suggests the existence of a direct relationship between educational level and entrepreneurship by opportunity, where $90.6 \%$ of individuals presented university education [28]; while the GUESSS report for Colombia, mentions 
that students have a higher propensity to work as employees upon graduation (73\%), but five years later they expect to create their own business [83].

\subsection{Marital status}

Marital status, having small children, and culture also have an impact on entrepreneurship [54,84], marriage can become a limiting factor in the case of women [85], but some findings suggest a weak interaction between entrepreneurship and marital status in the case of men [86]. Despite this, women have been gaining participation in entrepreneurial activity, motivated by the search for opportunities and the compensation of labor market imbalances [87,88].

The participation of single people in entrepreneurship is also advancing, especially those who have had work experience and academic preparation, who are motivated in part by existing working conditions, unemployment, or even the search for entrepreneurial opportunities in sectors they know or have worked in [50].

Recent studies speak of the contrast between single people who are more prone to risk because they do not have commitments as married people at the time of entrepreneurship; which would generate a constraint on people with family and economic obligations [55,89]; however, there is no consensus; because some scholars have also found that married people, compared to single people, have a greater chance of entrepreneurship in certain countries [90-92].

\subsection{Family environment and economic status.}

The incidence of the family environment and the economic condition of the individual has also been of interest for analyzing entrepreneurial activity [21], some studies document the intergenerational transmission of the occupation from parents to children, which is more significant among entrepreneurs than among workers [62], and where the children of self-employed workers have a higher entrepreneurial activity than other parents [93], which could be explained by the early learning of business skills [71].

The existence of role models favors the entrepreneurial activity of young people, although they do not necessarily have to be from their family environment [94]; the interaction of the subjects with successful people is a source of inspiration for the creation of new business initiatives [95,96]; which are influenced by personal conditions, family support, as well as access to financing and the favoring of institutional conditions [97].

Regarding the individual's income level and its impact on entrepreneurial activity, there is still no consensus, some studies suggest a positive relationship [98], while others suggest an inverse relationship [55]; this is partly because the objective of creating a business through necessity is affected by the economic conditions of the environment, but as resources grow, it is possible that the subjects intrinsically seek opportunities to increase their independence and income, which would also favor entrepreneurial activity [99].

\section{Materials and Methods}

\subsection{Study design}

A quantitative, cross-sectional methodology was used for the development of the research (single measurement through an online questionnaire between March and May 2020), and with correlational scope (possible relationships between variables); an in- 
strument constructed and validated by Arias, Ribes, and Arango [100] was used, which was developed using expert consultation, expert competence assessment and verification of internal consistency, using Cronbach's alpha, whose results exceeded the value of 0.9 for all cases (see Annex 1); considering the instrument adequate to develop the fieldwork.

\subsection{Population and sample}

Given the interest in promoting rural entrepreneurship and the positive associations between age and educational level found in the literature review, we sought to identify the association of the level of entrepreneurship with other types of sociodemographic variables such as the level of studies attained by the parents, marital status, number of dependents and socioeconomic stratum; associated with students in their last semester of studies and graduate students of the five faculties of agricultural sciences existing in the city of Medellin.

Taking into account the above, the participation of subjects belonging to the millennial population (the focus of the study) is guaranteed and an important range of ages, different educational levels, possible interest in rural entrepreneurship due to the relevance of their fields of study, different marital statuses, and socioeconomic strata are obtained.

When inquiring via telephone to the five deans of the different faculties about the number of students enrolled for the first semester of 2020, a total count of 1254 people enrolled was obtained. Taking this number as a reference, a sample size of 295 people was gathered, considering a confidence level of $95 \%$ and a margin of error of $5 \%$. Due to the above and subject to the difficulty caused by the Covid-19 pandemic, the questionnaire was distributed electronically from each of the faculties, obtaining a response rate of approximately $34 \%$, the description of the sample is presented in Table 2.

Table 2. Sample description.

\begin{tabular}{|c|c|c|c|}
\hline Variable & $\%$ & Variables & $\%$ \\
\hline Gender & & Marital status & \\
\hline 1. Male & 46 & 1. Single & 58 \\
\hline 2. Female & 54 & 2. Not single & 42 \\
\hline Last degree of studies & & Number of dependents & \\
\hline 1. Technician & 23 & 1. No one & 23 \\
\hline 2. Professional & 52 & 2. only one & 29 \\
\hline 3. Postgraduate & 26 & 3. two or more people & 48 \\
\hline Last grade of education (Mother) & & Last grade of education (Father) & data \\
\hline 1. Elementary school & 27 & 1. Elementary school & 36 \\
\hline 2. High School & 36 & 2. High School & 32 \\
\hline 3. University or postgraduate & 37 & 3. University or postgraduate & 32 \\
\hline \multicolumn{4}{|l|}{ Socioeconomic level } \\
\hline 1. Low level - low & 4 & & \\
\hline 2. Low level & 19 & & \\
\hline 3. Medium - low level & 36 & & \\
\hline 4. Medium level & 21 & & \\
\hline 5. Medium - high level & 12 & & \\
\hline 6. High level & 8 & & \\
\hline
\end{tabular}




\subsection{Response variable}

The level of entrepreneurship was measured based on the response to the question: What stage of entrepeneurship are you at?. Therefore, the level is 0 if the person prefers to work and is not interested in entrepreneurship, 1 if the person barely has the business idea, but has not started to develop it, and 2 if the person is starting or already has their business.

\subsection{Data analysis}

Once the level of entrepreneurship of the participants was identified, chi-square statistical tests were performed [101,102]; to determine whether this level has some degree of association with the different sociodemographic characteristics that were measured, such as age, marital status, gender, level of studies, among others.

Subsequently, once the existence of associations between the variables had been verified, a multiple correspondence analysis was performed [103]; to identify some patterns and trends between the variables. This technique was used to handle multivariate categorical data, such as those collected in the survey. The main idea of multiple correspondence analysis is the reduction of the dimensionality of the original data set into different components; generally, as a result of such analysis, perceptual maps with the first two components are obtained, thus facilitating interpretation [104].

\section{Results and discussion.}

The first step to establish the differences concerning the sociodemographic factors is detailed in Table 3, in which variables such as gender, marital status, age, educational level, and socioeconomic stratum are presented with the different levels of entrepreneurship; taking into account whether the respondent prefers to work and is not interested in entrepreneurship, whether he/she has a business idea but has not started to develop it, or whether he/she is starting or already has a business in operation.

The rejection of the null hypothesis of no association with the level of entrepreneurship is taken into account; the chi-square test statistics, with their degrees of freedom and p-values (bilateral significance), are presented at the bottom (see Table 3).

In the case of the gender variables, it is possible to observe differences in terms of the level of entrepreneurship corresponding with being a man or a woman. The probability of being in level 0 of entrepreneurship (not wanting to start a business) is higher for women (15.10\% for women and $8.90 \%$ for men). Likewise, it is observed that the probability of being in level 2 (starting the business or already having it in operation) is higher for men (42.90\% compared to $32.30 \%$ for women), which is in line with what is reported in the literature, which shows greater participation of the male gender in terms of entrepreneurship [54].

Table 3. Chi-square tests for sociodemographic factors.

\begin{tabular}{|c|c|c|c|c|c|c|}
\hline \multirow[b]{2}{*}{ Variable } & \multicolumn{3}{|c|}{ Level of entrepreneurship (\%) } & \multirow[b]{2}{*}{$\begin{array}{c}\text { Chi } \\
\text { square }\end{array}$} & \multirow[b]{2}{*}{ gl } & \multirow[b]{2}{*}{$\begin{array}{c}\text { bilateral } \\
\text { significance }\end{array}$} \\
\hline & 0 & 1 & 2 & & & \\
\hline Gender & & & & 6.783 & 2 & 0.034 \\
\hline 1 & 15.10 & 52.60 & 32.30 & & & \\
\hline 2 & 8.90 & 48.20 & 42.90 & & & \\
\hline Marital status & & & & 8.671 & 2 & 0.013 \\
\hline 1 & 13.80 & 54.10 & 32.1 & & & \\
\hline
\end{tabular}




\begin{tabular}{|c|c|c|c|c|c|c|}
\hline 2 & 9.50 & 44.40 & 46.20 & & & \\
\hline$\overline{\text { Age }}$ & & & & 29.411 & 6 & 0.000 \\
\hline$[18,24]$ & 17.10 & 66.70 & 16.20 & & & \\
\hline$[25,31]$ & 9.60 & 47.10 & 43.40 & & & \\
\hline$[32,38]$ & 8.60 & 41.90 & 49.50 & & & \\
\hline$>=39$ & 12.50 & 45.50 & 42.00 & & & \\
\hline Education & & & & 18.205 & 4 & 0.001 \\
\hline 1 & 16.00 & 12.30 & 7.30 & & & \\
\hline 2 & 62.80 & 48.90 & 43.10 & & & \\
\hline 3 & 31.30 & 38.80 & 49.50 & & & \\
\hline Socioeconomic level & & & & 38.737 & 10 & 0 \\
\hline 1 & 10.50 & 68.40 & 21.10 & & & \\
\hline 2 & 6.10 & 69.50 & 24.40 & & & \\
\hline 3 & 15.40 & 53.00 & 31.50 & & & \\
\hline 4 & 13.50 & 36.00 & 50.60 & & & \\
\hline 5 & 7.80 & 49.00 & 43.10 & & & \\
\hline 6 & 12.50 & 21.90 & 65.60 & & & \\
\hline
\end{tabular}

Regarding marital status, the probability of being in level 2 of entrepreneurship is lower if single (32.10\% compared to $46.20 \%$ for a situation other than single), which would favor those who live with a partner, given the possibility of having better conditions and support from a spouse for entrepreneurship [55].

Regarding the differences in the level of entrepreneurship according to the age categories among the respondents, not wanting to participate (level of entrepreneurship 0) is higher for people under 24 years of age compared to those between 25 and 38 years of age (age categories 2 and 3).

Regarding the educational level of the respondent, differences were also found in the levels of entrepreneurship, since, for example, the probability of not wanting to undertake is lower if the person has reached a postgraduate level of studies, a situation that would occur in this segment due to a better possibility of access to a formal job [74].

Similarly, those who are less likely to be in level 2 of entrepreneurship are those who did not exceed the technological level (21.30\% compared to $38.80 \%$ of those who did not exceed professional studies and $49.50 \%$ of those who have postgraduate studies), which would suggest a favorable relationship between the educational level achieved by the person and his or her possibility of entrepreneurship.

Finally, regarding the socioeconomic stratum of the respondents, the probabilities of being in level 2 of entrepreneurship are higher if the person belongs to strata 4, 5, and 6 (see Table 2); the latter stratum having the highest percentage with $65.60 \%$, compared to $21.10 \%$ of stratum 1 ; these results suggest the favorability of people with higher income to promote their businesses, compared to those who have a lower economic status.

For the variables of the educational level of the father/mother and number of dependents, chi-square statistical tests were also performed; but no association was found, and therefore, it was not possible to reject independence concerning the level of entrepreneurship. The values for the father's level of education were: Chi-square $=6.996, \mathrm{gl}=4$, and Bilateral sig. $=0.136$. The values for educational level of the mother were: Chi-square $=7.096, \mathrm{gl}=4$ and bilateral significance $=0.131$ and for the number of dependents: Chi-square $=7.321, \mathrm{gl}=4$ and bilateral significance $=0.120$. 
Since there are interesting associations between the level of entrepreneurship and the sociodemographic variables measured, a multiple correspondence analysis was carried out to identify certain patterns and behavioral trends. Table 4 presents a summary with Cronbach's alpha and the variance explained by the two dimensions extracted and the corresponding reduction of the selected variables. It can be seen that the two dimensions have approximately the same weight (inertia values of .282 and .255, respectively for 1 and 2 .

Table 4. Summary of multiple correspondence analysis

\begin{tabular}{cccc}
\hline & \multicolumn{3}{c}{ Variance explained } \\
\cline { 2 - 4 } Dimension & Cronbach's alpha & Total (Autovalues) & Inertia \\
\cline { 2 - 4 } 1 & 0.682 & 2.537 & 0.282 \\
2 & 0.634 & 2.292 & 0.255 \\
Total & & 4.828 & 0.536 \\
Mean & 0.659 & 2.414 & 0.269 \\
\hline
\end{tabular}

Figure 1, on the other hand, presents the joint graph of points in the different categories of the variables analyzed. The greater the proximity between the categories of the variables, the greater the degree of association between them. The colored ovals arranged in the Figure help to visualize some patterns according to the level of entrepreneurship (Empr_C, in its levels 0, 1, and 2) and the rest of the sociodemographic variables measured.

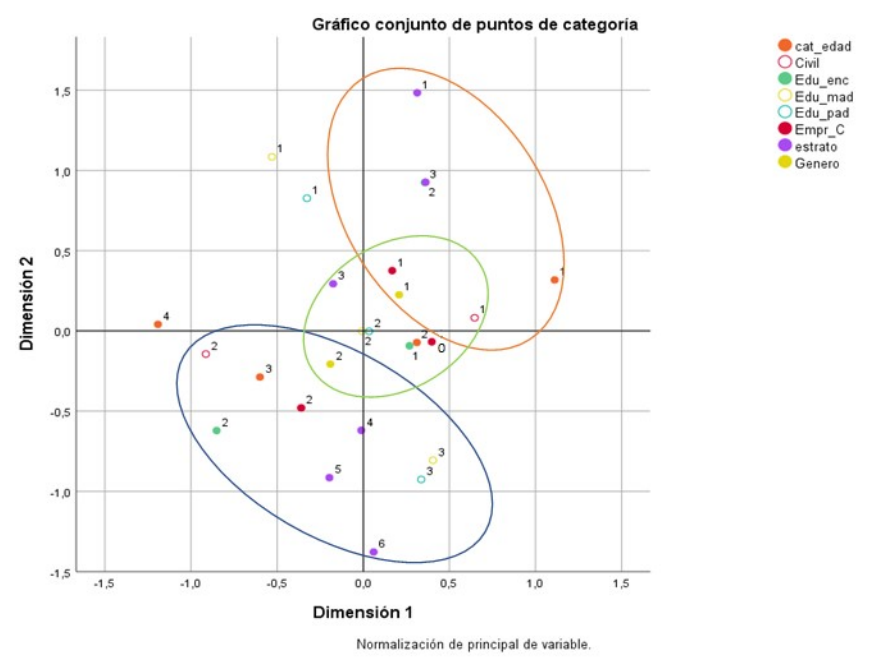

Figure 1. Multiple correspondence analysis

The blue oval corresponds to the category of those who are already entrepreneurs (level 2 of entrepreneurship) and are associated with high socioeconomic strata of the population (purple 4, 5, and 6), also with postgraduate studies (green filled 2), parents with university and/or postgraduate degrees (yellow outline 3 and green 3), ages between 32 and 38 years old (orange 3), with a marital status other than single (pink outline 2) and were predominantly men (yellow filled 2); This indicates the favorability that people belonging to the upper classes of the population have for entrepreneurship in the rural sector and whose environments and socioeconomic condition are more favorable than those belonging to a lower stratification. 
The orange oval corresponds to people who barely have the idea of entrepreneurship (level 1 of entrepreneurship), who are associated with strata 1 and 2 (purple 1 and 2), i.e. those with lower income levels; predominantly women (yellow filled 1), people in this category are 24 years old or younger (orange 1), their educational status is at a technological level (green filled 3) and they are single (pink outline 1).

The green oval indicates those who do not want to be entrepreneurs but want to work (level 0 entrepreneurship), are associated with stratum 3 (purple 3), have a university education (green filled 1), are between 25 and 31 years old (orange 2), are single (pink outline 1) and have parents with education no higher than high school (yellow outline 2 and green 2).

\section{Conclusions}

The blue oval corresponds to the category of those who are already entrepreneurs (level 2 of entrepreneurship) and are associated with high socioeconomic strata of the population (purple 4,5, and 6), also with postgraduate studies (green filled 2), parents with university and/or postgraduate degrees (yellow outline 3 and green 3 ), ages between 32 and 38 years old (orange 3), with a marital status other than single (pink outline 2) and were predominantly men (yellow filled 2); This indicates the advantage people have when belonging to the upper classes of the population with specific reference to entrepreneurship in the rural sector and whose environments and socioeconomic condition are more favorable than those belonging to a lower stratification.

The orange oval corresponds to people who barely have the idea of entrepreneurship (level 1 of entrepreneurship), who are associated with strata 1 and 2 (purple 1 and 2), i.e. those with lower income levels; predominantly women (yellow filled 1), people in this category are 24 years old or younger (orange 1), their educational status is at a technological standard (green filled 3) and they are single (pink outline 1).

The green oval indicates those who do not want to be entrepreneurs but want to work (level 0 entrepreneurship), are associated with stratum 3 (purple 3), have a university education (green filled 1), are between 25 and 31 years old (orange 2), are single (pink outline 1 ) and have parents with education no higher than high school (yellow outline 2 and green 2).

Author Contributions: Conceptualization: F.A., G.R., Fieldwork: F.A., G.R., Methodology: F.A., G.R., Statistical processing: D.A., F.A., Writing, and editing: F.A., G.R., Financing: F.A, G.R., LFG. All authors have read and agreed to the published version of the manuscript.

Funding: This research was funded by the Corporación Universitaria Americana and the Universitat Politècnica de València, in the largest call with the project entitled "Characterization of Motivational Factors in the young population in a subregion of Antioquia and its relationship with Rural Entrepreneurship".

Acknowledgments: The authors thank Ph.D. Luis Fernando Garces Giraldo for his support in research management.

Conflicts of Interest: The authors declared no conflict of interest. It was no role of the funders in designing the study; in collecting, analyzing, or interpreting results; in the writing of the paper, or in the decision to publish the results. 


\section{References}

1. Kirkwood, J. Motivational factors in a push-pull theory of entrepreneurship. Gend. Manag. An Int. J. 2009, 24, 346-364, doi:10.1108/17542410910968805.

2. Reynolds, P.D.; Camp, M.; Autio, E. Global Entrepreneurship Monitor: 2001 Executive Report; Entreworld: London, 2001;

3. Meoli, A.; Fini, R.; Sobrero, M.; Wiklund, J. How entrepreneurial intentions influence entrepreneurial career choices: The moderating influence of social context. J. Bus. Ventur. 2020, 35, doi:10.1016/j.jbusvent.2019.105982.

4. Acs, Z. How Is Entrepreneurship Good for Economic Growth? Innov. Technol. Governance, Glob. 2006, 1, 97-107, doi:10.1162/itgg.2006.1.1.97.

5. Coulibaly, S.K.; Erbao, C.; Metuge Mekongcho, T. Economic globalization, entrepreneurship, and development. Technol. Forecast. Soc. Change 2018, 127, 271-280, doi:10.1016/j.techfore.2017.09.028.

6. Urbano, D.; Aparicio, S.; Audretsch, D. Twenty-five years of research on institutions, entrepreneurship, and economic growth: what has been learned? Small Bus. Econ. 2019, 53, 21-49, doi:10.1007/s11187-018-0038-0.

7. Boudreaux, C.; Nikolaev, B. Entrepreneurial Traits, Institutions, and the Motivation to Engage in Entrepreneurship. Acad. Manag. Proc. 2017, 2017, 16427, doi:10.5465/AMBPP.2017.33.

8. Van der Zwan, P.; Thurik, R.; Verheul, I.; Hessels, J. Factors influencing the entrepreneurial engagement of opportunity and necessity entrepreneurs. Eurasian Bus. Rev. 2016, 6, 273-295, doi:10.1007/s40821-016-0065-1.

9. Harpa, E. Macroeconomic Analysis of the Competitive Factors which Influence Innovation in Rural Entrepreneurship. Procedia Eng. 2017, 181, 965-968, doi:10.1016/j.proeng.2017.02.494.

10. Hessels, J.; van Gelderen, M.; Thurik, R. Entrepreneurial aspirations, motivations, and their drivers. Small Bus. Econ. 2008, 31, 323-339, doi:10.1007/s11187-008-9134-x.

11. Block, J.H.; Wagner, M. Necessity and Opportunity Entrepreneurs in Germany: Characteristics and Earning s Differentials. Schmalenbach Bus. Rev. 2010, 62, 154-174, doi:10.1007/BF03396803.

12. Fossen, F.M.; Büttner, T.J.M. The returns to education for opportunity entrepreneurs, necessity entrepreneurs, and paid employees. Econ. Educ. Rev. 2013, 37, 66-84, doi:10.1016/j.econedurev.2013.08.005.

13. Laure Humbert, A.; Drew, E. Gender, entrepreneurship and motivational factors in an Irish context. Int. J. Gend. Entrep. 2010, 2, 173-196, doi:10.1108/17566261011051026.

14. Raquel, F. La motivación emprendedora y los factores que contribuyen con el éxito del emprendimiento. Ciencias Adm. 2013, 1-10.

15. Vargas, G. Influencia de la motivacion de logro, actitud emprendedora, y autoeficacia emprendedora, sobre la intencion emprendedora en los estudiantes del área de ciencias empresariales de la Universidad Nacional San Antonio Abad Del Cusco, Universidad Nacional Mayor de San Marcos, 2007.

16. Baumeister, R.F. Toward a general theory of motivation: Problems, challenges, opportunities, and the big picture. Motiv. Emot. 2016, 40, 1-10, doi:10.1007/s11031-015-9521-y.

17. Sánchez, J.; Aldana, R.; De Dios, S.; Yurrebasco, A. La motivación y la intención emprendedora. Int. J. Dev. Educ. Psychol. 2012, 4, 521-531.

18. Palmero, F.; Fernandez, E.; Choliz, M.; Martínez, F. Psicología de la motivación y emoción; Mc Graw Hill: Madrid, 2002;

19. Shapero, A. The entrepreneurial event; Ohio State University: Ohio, 1985;

20. Marulanda, F.Á.; Morales, S.T. Entorno y motivaciones para emprender. Rev. EAN 2017, 12, doi:10.21158/01208160.n81.2016.1556.

21. Tarapuez, E.; Aristizábal, J.M.; Monard, C. Aspectos sociodemográficos y familiares e intención empresarial en estudiantes de Maestría en Administración en Colombia. Estud. Gerenciales 2018, 34, 422-434, doi:10.18046/j.estger.2018.149.2757.

22. Marulanda, F.Á.; Montoya, I.A.; Vélez, J.M. Teorías motivacionales en el estudio del emprendimiento. Pensam. Gestión. 2014, 204-236, doi:10.14482/pege.36.5571.

23. Sanclemente, J.C. La colonización antioqueña, el emprendimiento y su aporte a la competitividad regional y nacional. Estud. Gerenciales 2010, 26, 119-147, doi:10.1016/S0123-5923(10)70105-4.

24. Gobernación de Antioquia Acta de reunión consea; Medellin, 2019;

25. Mincomercio Información : Perfiles Económicos Departamentales; Oficina de Estudios Económicos Febrero 2021; Bogotá, 2021;

26. Arias, F.; Ribes-Giner, G.; Arango, D. Drivers, barreras y motivaciones para el emprendimiento rural de los millennials en Antioquia-Colombia. Rev. Ciencias Soc. 2020, 26.

27. Arias, F.; Ribes, G.; Arango, D. Impulsores, barreras y motivaciones para el emprendimiento rural de los millennials en Antioquia-Colombia/ Drivers, barriers and motivations for rural entrepreneurship of millennials in Antioquia-Colombia. Rev. Ciencias Soc. 2020, XXVI, 56-70, doi:10.31876/rcs.v26i3.33231.

28. Laverde, F.; Osorio, F.; Medina, L.; Varela, R.; Gomez, E.; Parra, L.D.; Matiz, F.; Buelvas, P.; Gomez, L.; Rueda, F. Estudio de la Actividad Emprendedora en Colombia - GEM Colombia; Universidad Javeriana: Bogotá, 2019;

29. Cantillon, R. Essai sur la Nature du Commerce; Chez Fletcher Gyles: Londres, 1756;

30. Casson, M. A history of entrepreneurship - By Robert F. Hébert and Albert N. Link. Econ. Hist. Rev. 2010, 63, 1205-1206, doi:10.1111/j.1468-0289.2010.00551_33.x. 
31. Dana, L. World Encyclopedia of Entrepreneurship; Edward Elgar Publishing: Cheltenham, 2011; ISBN 9781849808453.

32. Ahmad, N.; Seymour, R. Defining Entrepreneurial Activity: Definitions Supporting Frameworks for Data Collection; París, 2008;

33. Álvarez, C.; Urbano, D.; Amorós, J.E. GEM research: Achievements and challenges. Small Bus. Econ. 2014, 42, doi:10.1007/s11187-013-9517-5.

34. Almodovar, M. Actividad Emprendedora y Desarrollo Económico ., Universidad de Extremadura, 2016.

35. Reynolds, P.D. Understanding Business Creation: Serendipity and Scope in Two Decades of Business Creation Studies. Small Bus. Econ. 2005, 24, 359-364, doi:10.1007/s11187-005-0692-x.

36. Singer, S.; Amorós, E.; Moska, D. Global Entrepreneurship Monitor 2014 Global Report; 2015;

37. Wong, P.K.; Ho, Y.P.; Autio, E. Entrepreneurship, Innovation and Economic Growth: Evidence from GEM data. Small Bus. Econ. 2005, 24, 335-350, doi:10.1007/s11187-005-2000-1.

38. van Stel, A.; Storey, D.J.; Thurik, A.R. The Effect of Business Regulations on Nascent and Young Business Entrepreneurship. Small Bus. Econ. 2007, 28, 171-186, doi:10.1007/s11187-006-9014-1.

39. Klapper, L.; Amit, R.; Guillen, M.F.; Quesada, J.M. Entrepreneurship And Firm Formation Across Countries; Policy Research Working Papers; World Bank: Washington, 2007;

40. Acz, Z.; Szerb, L.; Autio, E. Global entrepreneurship index; GEDI: Washington, 2015;

41. OECD OECD Labour Force Statistics 2014; 2015;

42. Commission of the european communities Green Paper Entrepreneurship in Europe; Brussels, 2003; Vol. 18;

43. Chandra, Y. Mapping the evolution of entrepreneurship as a field of research (1990-2013): A scientometric analysis. PLoS One 2018, 13, e0190228, doi:10.1371/journal.pone.0190228.

44. Ferreira, J.J.M.; Fernandes, C.I.; Kraus, S. Entrepreneurship research: mapping intellectual structures and research trends. Rev. Manag. Sci. 2019, 13, 181-205, doi:10.1007/s11846-017-0242-3.

45. Perényi, Á.; Losoncz, M. A Systematic Review of International Entrepreneurship Special Issue Articles. Sustainability 2018, 10, 3476, doi:10.3390/su10103476.

46. Muñoz, P.; Cohen, B. Sustainable Entrepreneurship Research: Taking Stock and looking ahead. Bus. Strateg. Environ. 2018, 27, 300-322, doi:10.1002/bse.2000.

47. Terán-Yépez, E.; Marín-Carrillo, G.M.; Casado-Belmonte, M. del P.; Capobianco-Uriarte, M. de las M. Sustainable entrepreneurship: Review of its evolution and new trends. J. Clean. Prod. 2020, 252, 119742, doi:10.1016/j.jclepro.2019.119742.

48. Pato, M.L.; Teixeira, A.A.C. Twenty Years of Rural Entrepreneurship: A Bibliometric Survey. Sociol. Ruralis 2016, 56, 3-28, doi:10.1111/soru.12058.

49. Arias, F.; Ribes Giner, G. Evolución del papel del emprendedor rural : del agricultor subordinado del siglo XVIII al empresario rural actual. Rev. Venez. Gerenc. 2019, 24, 1005-1028.

50. Gomez, E.J. Ensayos sobre la actividad emprendedora de los jóvenes españoles desde una perspectiva territorial., Universidad Autónoma de Barcelona, 2014.

51. McElwee, G. A taxonomy of entrepreneurial farmers. Int. J. Entrep. Small Bus. 2008, 6, 465-478, doi:10.1504/IJESB.2008.019139.

52. Lafuente, E.; Gómez-Araujo, E. The Territorial Economic Impact of Entrepreneurial Youthfulness. Strateg. Chang. 2016, 25, 187-204, doi:10.1002/jsc.2055.

53. Mancilla, C.; Amoros, E.; Vaillant, Y. Análisis de las primeras etapas del proceso emprendedor. Rev. Chil. Econ. y Soc. 2016, 13-22.

54. Diaz, J.C.D.; Hernandez, R.; Sanchez, M. de la C.; Postigo, M.V. Actividad emprendedora y género. Un estudio comparativo. Rev. Eur. Dir. y Econ. la Empres. 2010, 19, 83-98.

55. León Mendoza, J. Emprendimiento de negocios propios en el Perú: el rol de los factores sociodemográficos personales a nivel de departamentos. Estud. Gerenciales 2018, 34, 19-33, doi:10.18046/j.estger.2018.146.2810.

56. Zengyu, V.; Nandialath, A.; Kassim, A.; Esra, E. Socio-demographic factors and network configuration among MENA entrepreneurs. Int. J. Emerg. Mark. 2013, 8, 258-281, doi:10.1108/17468801311330329.

57. Raposo, M.; Paço, A. Entrepreneurship education : Relationship between education. Psicothema 2011, $23,453-457$.

58. Dilli, S.; Westerhuis, G. How institutions and gender differences in education shape entrepreneurial activity: a cross-national perspective. Small Bus. Econ. 2018, 51, 371-392, doi:10.1007/s11187-018-0004-x.

59. Hernández, B.R.; Sánchez, J.C.; Mayens, A.W. Impact of Entrepreneurial Education Programs on Total Entrepreneurial Activity: The Case of Spain. Adm. Sci. 2019, 9, 25, doi:10.3390/admsci9010025.

60. Canales, R.; Román, Y.; Ovando, W. Emprendimiento de la población joven en México. Una perspectiva crítica. Entreciencias Diálogos en la Soc. del Conoc. 2017, 5, doi:10.21933/j.edsc.2017.12.211.

61. Tarapuez, E.; García, M.D.; Castellano, N. Aspectos socioeconómicos e intención emprendedora en estudiantes universitarios del Quindío (Colombia). Innovar 2018, 28, 123-135, doi:10.15446/innovar.v28n67.68618.

62. Ferrando, S.; Velilla, J.; Ortega, R. Intergenerational Transmission of Entrepreneurial Activity in Spanish Families. J. Fam. Econ. Issues 2019, 40, 390-407, doi:10.1007/s10834-019-09613-7.

63. Meek, W.R.; Pacheco, D.F.; York, J.G. The impact of social norms on entrepreneurial action: Evidence from the environmental entrepreneurship context. J. Bus. Ventur. 2010, 25, 493-509, doi:10.1016/j.jbusvent.2009.09.007. 
64. Wu, J.; Li, Y.; Zhang, D. Identifying women's entrepreneurial barriers and empowering female entrepreneurship worldwide: a fuzzy-set QCA approach. Int. Entrep. Manag. J. 2019, 15, 905-928, doi:10.1007/s11365-019-00570-z.

65. Koellinger, P.; Minniti, M.; Schade, C. Gender Differences in Entrepreneurial Propensity*. Oxf. Bull. Econ. Stat. 2013, 75, 213-234, doi:10.1111/j.1468-0084.2011.00689.x.

66. Hechavarría, D.M.; Terjesen, S.A.; Stenholm, P.; Brännback, M.; Lång, S. More than Words: Do Gendered Linguistic Structures Widen the Gender Gap in Entrepreneurial Activity? Entrep. Theory Pract. 2018, 42, 797-817, doi:10.1177/1042258718795350.

67. Ribes-Giner, G.; Moya-Clemente, I.; Cervelló-Royo, R.; Perello-Marin, M.R. Domestic economic and social conditions empowering female entrepreneurship. J. Bus. Res. 2018, 89, 182-189, doi:10.1016/j.jbusres.2017.12.005.

68. Sarfaraz, L.; Faghih, N.; Majd, A. The relationship between women entrepreneurship and gender equality. J. Glob. Entrep. Res. 2014, 2, 6, doi:10.1186/2251-7316-2-6.

69. Yurrebaso, A.; Rodríguez, C.; Jáñez, Á.; Picado, E.M.; Guzmán, R.; Pérez, J.L. Personalidad emprendedora y género. Cuad. Relac. Laborales 2020, 38, 85-103, doi:10.5209/crla.68869.

70. Lewellyn, K.B.; Muller-Kahle, M.I. A configurational approach to understanding gender differences in entrepreneurial activity: a fuzzy set analysis of 40 countries. Int. Entrep. Manag. J. 2016, 12, 765-790, doi:10.1007/s11365-015-0366-3.

71. Bernat, L.F.; Lambardi, G.; Palacios, P. Determinants of the entrepreneurial gender gap in Latin America. Small Bus. Econ. 2017, 48, 727-752, doi:10.1007/s11187-016-9789-7.

72. Caliendo, M.; Fossen, F.M.; Kritikos, A.; Wetter, M. The Gender Gap in Entrepreneurship: Not just a Matter of Personality. CESifo Econ. Stud. 2015, 61, 202-238, doi:10.1093/cesifo/ifu023.

73. GEM Actividad Empresarial Colombiana; Universidad del Norte: Barranquilla, 2017; ISBN 9789588936222.

74. Berrill, J.; O'Hagan-Luff, M.; van Stel, A. The moderating role of education in the relationship between FDI and entrepreneurial activity. Small Bus. Econ. 2020, 54, 1041-1059, doi:10.1007/s11187-018-0121-6.

75. Shi, L.; Yao, X.; Wu, W. Perceived university support, entrepreneurial self-efficacy, heterogeneous entrepreneurial intentions in entrepreneurship education. J. Entrep. Emerg. Econ. 2019, 12, 205-230, doi:10.1108/JEEE-04-2019-0040.

76. Hasan, S.M.; Khan, E.A.; Nabi, M.N.U. Entrepreneurial education at university level and entrepreneurship development. Educ. + Train. 2017, 59, 888-906, doi:10.1108/ET-01-2016-0020.

77. Sánchez, J.C. The Impact of an Entrepreneurship Education Program on Entrepreneurial Competencies and Intention. J. Small Bus. Manag. 2013, 51, 447-465, doi:10.1111/jsbm.12025.

78. Nabi, G.; Liñán, F.; Fayolle, A.; Krueger, N.; Walmsley, A. The Impact of Entrepreneurship Education in Higher Education: A Systematic Review and Research Agenda. Acad. Manag. Learn. Educ. 2017, 16, 277-299, doi:10.5465/amle.2015.0026.

79. Hahn, D.; Minola, T.; Bosio, G.; Cassia, L. The impact of entrepreneurship education on university students' entrepreneurial skills: a family embeddedness perspective. Small Bus. Econ. 2020, 55, 257-282, doi:10.1007/s11187-019-00143-y.

80. Oosterbeek, H.; van Praag, M.; Ijsselstein, A. The impact of entrepreneurship education on entrepreneurship skills and motivation. Eur. Econ. Rev. 2010, 54, 442-454, doi:10.1016/j.euroecorev.2009.08.002.

81. García, F.J.; Ruiz, C.-I.; Gil, E.; Gutiérrez, D. Promoting entrepreneurship education among university students: design and evaluation of an intervention programme / Fomento de la educación emprendedora entre el alumnado universitario: diseño y evaluación de un programa de intervención. Cult. y Educ. 2016, 28, 565-600, doi:10.1080/11356405.2016.1196897.

82. Uhlaner, L.; Thurik, R. Postmaterialism Influencing Total Entrepreneurial Activity Across Nations. In Entrepreneurship and Culture; Springer Berlin Heidelberg: Berlin, Heidelberg, 2010; pp. 301-328.

83. Martins, I.; Pérez, J.; Álvarez, C.; López, T.; Moreno, J.; Hugueth, A. El espíritu emprendedor de los estudiantes en Colombia. Resultados del Proyecto Guesss 2018. 2019, 73.

84. Amorós, E.; Guerra, M.; Pizarro, O.; Poblete, C. Mujeres y Actividad Emprendedora en Chile; Gem Consortion: Santiago de Chile, 2012; ISBN 9789567961696.

85. Pérez, C.; Avilés, M. Explanatory factors of female entrepreneurship and limiting elements. Suma Negocios 2016, 7, 25-31, doi:10.1016/j.sumneg.2015.12.004.

86. Krasniqi, B.A. Personal, household and business environmental determinants of entrepreneurship. J. Small Bus. Enterp. Dev. 2009, 16, 146-166, doi:10.1108/14626000910932935.

87. Santander, P.; Fernández, C.; Yáñez, D. Motivaciones y condicionantes contextuales en el emprendimiento liderado por mujeres chilenas. Rev. Ciencias Soc. 2016, 22, 63-77.

88. Ribes-Giner, G.; Moya-Clemente, I.; Cervelló-Royo, R.; Perello-Marin, M.R. Wellbeing indicators affecting female entrepreneurship in OECD countries. Qual. Quant. 2019, 53, 915-933, doi:10.1007/s11135-018-0796-4.

89. Tovar, L.; Balanta, S.; Ordoñez, J.; Serna, W. Factores asociados al emprendimiento por oportunidad de los colombianos restornados del exterior. Migraciones 2018, 45, 119-142, doi:10.mig.i45.y2018.005.

90. Corradin, S.; Popov, A. House prices, home equity and entrepreneurships; 2013;

91. Özcan, B. Only the lonely? The influence of the spouse on the transition to self-employment. Small Bus. Econ. 2011, 37, 465-492, doi:10.1007/s11187-011-9376-x.

92. de la O Cordero, D.; Urbano Pulido, D. Female entrepreneurial activity in Latin-America: A literature review within perspective of Institutional Theory. Act. Empres. Femenina en Latinoamérica Una revisión Lit. bajo la Perspect. la Teoría Inst. $2020,5,9$. 
93. Álvarez, C.; Urbano, D. Factores del entorno y actividad emprendedora en américa latina. Acad. Rev. Latinoam. Adm. 2011, 16760, 31-45.

94. Nicolaou, N.; Shane, S. Can genetic factors influence the likelihood of engaging in entrepreneurial activity? J. Bus. Ventur. 2009, 24, 1-22, doi:10.1016/j.jbusvent.2007.11.003.

95. Echeverri, L.; Valencia, A.; Benjumea, M.; Barrera, A. Factores que inciden en la intención emprendedora del estudiantado universitario: Un análisis cualitativo. Rev. Electrónica Educ. 2018, 22, 1, doi:10.15359/ree.22-2.10.

96. Zapkau, F.B.; Schwens, C.; Steinmetz, H.; Kabst, R. Disentangling the effect of prior entrepreneurial exposure on entrepreneurial intention. J. Bus. Res. 2015, 68, 639-653, doi:10.1016/j.jbusres.2014.08.007.

97. Alvarez, C.; Urbano, D.; Coduras, A.; Ruiz-Navarro, J. Environmental conditions and entrepreneurial activity: a regional comparison in Spain. J. Small Bus. Enterp. Dev. 2011, 18, 120-140, doi:10.1108/14626001111106460.

98. Capelleras, J.L.; Contín, I.; Martin, V.; Larraza, M. La influencia de las percepciones individuales y el entorno rural/urbano en la actividad emprendedora naciente. Investig. Reg. 2013, 26, 97-113.

99. Jaén, I.; Fernández, J.; Liñán, F. Cultural values, income level and entrepreneurship | Valores culturales, nivel de ingres os y actividad emprendedora. Rev. Econ. Mund. 2013.

100. Arias, F.; Ribes Giner, G.; Arango, D. Impulsores, barreras y motivaciones para el emprendimiento rural de los millennials en Antioquia-Colombia/ Drivers, barriers and motivations for rural entrepreneurship of millennials in Antioquia-Colombia. Rev. Ciencias Soc. 2020, 26, 56-70, doi:10.31876/rcs.v26i3.33231.

101. Wuensch, K.L. Chi-Square Tests. In International Encyclopedia of Statistical Science; Springer Berlin Heidelberg: Berlin, Heidelberg, 2011; pp. 252-253.

102. Weaver, K.F.; Morales, V.; Dunn, S.L.; Godde, K.; Weaver, P.F. Chi-Square Test. In An Introduction to Statistical Analysis in Research; John Wiley \& Sons, Inc.: Hoboken, NJ, USA, 2017; pp. 393-434.

103. Le Roux, B.; Rouanet, H. Multiple Correspondence Analysis; SAGE Publications, Inc.: 2455 Teller Road, Thousand Oaks California 91320 United States of America, 2010; ISBN 9781412968973.

104. Fort, E.; Gadegbeku, B.; Gat, E.; Pelissier, C.; Hours, M.; Charbotel, B. Working conditions and risk exposure of employees whose occupations require driving on public roads - Factorial analysis and classification. Accid. Anal. Prev. 2019, 131, 254-267, doi:10.1016/j.aap.2019.07.001. 